\title{
Missionaries and Philology and Anthropology
}

\section{Author(s): James Sibree}

Source: The Geographical Journal, Vol. 28, No. 6 (Dec., 1906), pp. 644-645

Published by: geographicalj

Stable URL: http://www.jstor.org/stable/1776062

Accessed: 08-05-2016 01:32 UTC

\section{Your use of the JSTOR archive indicates your acceptance of the Terms \& Conditions of Use, available at}

http://about.jstor.org/terms

JSTOR is a not-for-profit service that helps scholars, researchers, and students discover, use, and build upon a wide range of content in a trusted digital archive. We use information technology and tools to increase productivity and facilitate new forms of scholarship. For more information about JSTOR, please contact support@jstor.org.

The Royal Geographical Society (with the Institute of British Geographers), Wiley are collaborating with JSTOR to digitize, preserve and extend access to The Geographical Journal 
passes leading into Tibet north of Katmandu can now be located with a fair approximation to exactness" is purely mythical.

October 29, 1906.

J. R. Hobday, Colonel, Late officiating Surveyor-General of India.

\section{Missionaries and Philology and Anthropology.}

I was much interested in reading Prof. Haddon's paper in the August number of the Journal, proposing a systematic investigation of the biology and anthropology of Melanesia, and I sincerely hope that such an expedition may be organized. But I ask your permission to take exception to some remarks made in the discussion following the paper, because they are most unjust to a large body of men who have done an immense deal in various parts of the world to advance the knowledge of language and of folk-lore. I notice that Mr. Ray said that "the missionaries learn the languages, to a certain extent, far enough to be able to produce a Gospel translation, and when that is published, they rarely go any further. Very few of them take down native stories, and no native literature is preserved." Now, both these statements are very far from the truth. I affirm, on the contrary, that no missionary is content with translating a single Gospel, but that the object of every Protestant mission is to give the peoples among whom it works all the New Testament in the first place, and then the complete sacred Scriptures. The annual reports of the Bible Society will fully confirm what I say, and will show that every year missionaries are going on to complete the whole Bible in countries where it is not already completed; and, more than that, they are continually revising and improving first translations as their knowledge of the various languages becomes more perfect. I may cite Mr. R. N. Cust's book, 'A Sketch of the Modern Languages of the East Indies' (Trübner, 1878), Appendix G, to show what had been done by missionaries in the large Indian group of languages nearly thirty years ago, and there have been great advances since. It is the same in China now-a large body of missionaries from all the Protestant Societies are engaged in a careful revision of the Bible; and it was the same with us here in Madagascar. The first missionaries here were indefatigable in completing the New Testament within two years of their arrival, and the whole Bible before they had been fifteen years in the island. And it is the same with my friends of the L.M.S. Mission in New Guinea now. Dr. Lawes, after barely ten years in a part of the island where the language was previously utterly unknown, returned to England with a complete translation of the New 'l'estament, not "a Gospel translation," to be printed by the Bible Society. And although the work is most difficult there in consequence of the number of languages, good progress is being made in studying several of them, and in giving the people the Scriptures in their own tongues. The fullest statement, and most carefully arranged account of what missionaries have done and are doing for philology is, however, given in the Rev. D. Dennis's monumental work, 'Christian Missions and Social Progress,' in three volumes, with a volume of statistics (New York : Revell Company), just completed. Such remarks as those made by some gentlemen are amply refuted by an inspection of facts and figures carefully compiled in Dr. Dennis's volumes. Missionaries have no need to be ashamed of their brethren as scholars, when such names are mentioned as Carey, and Hay, and Chamberlain, and Sherring in India; as Morrison, Milne, Legge, Edkins, and Griffith Johns in China; as Jones, and Griffiths, and Cousins, and Dahle in Madagascar; as Pattison, and Codrington, and Turner, and Wyatt Gill in Polynesia : but the list would be too long were I to attempt to make it anything like 
complete. All philologists know, and will gladly acknowledge, the debt their science owes to missionaries in all parts of the world, from the time of John Eliot down to the present day.

A word or two more as regards the second statement, viz. that "very few of them take down native stories, and no native literature is preserved." This is equally inaccurate, and I affirm, on the contrary, that numbers of missionaries are very anxious to preserve and study the folk-lore of the peoples among whom they live, and that a large amount of such material has been obtained by them and put on record. A way from access to libraries as I am in this country, I cannot try to give anything like a complete list, and can only give a few examples; but a reference to the volumes of the Folk-lore Society's proceedings will confirm ny statements. As an instance, however, I may just say that here in Madagascar very full lists have been compiled and printed of the native proverbs, and a great many have been translated; two considerable books have been printed, giving a large number of folk-tales, songs, conundrums, children's games, etc., as well as the curious ideas of divination, charms, etc. (in fact, a few of us a few years ago formed a little society for the collection and publication of such literature); smaller books have also been issued, giving native customs, speeches, etc., at marriages, funerals, circumcision festivals, and royal speeches, all of which preserve obsolete or obsolescent forms of the language. I myself have taken much interest in the dialects of the island, and an now proposing a plan to the Académie Malgache for their systematic collection and study; and Dr. Dahle, of the Lutheran Mission, has made exhaustive studies of the divination practices of the people, and also of the language. Now, what we have done here is not an exceptional fact by any means; witness Dr. 'Turner's book, 'Nineteen Years in Polynesia;' Rev. Wyatt Gill's 'Historical Sketches of Savage Life in Polynesia, with Illustrative Clan Songs;' and 'Myths and Songs from the South Pacific;' Dr. Codrington's 'The Melanesians : their Anthropology and Folk-lore;' Rev. W. Ellis's 'Polynesian Researches;' Rev. R. 'Iaylor's 'New Zealand and its Inhabitants;' Rev. M. A. Sherring's 'I'ribes and Castes of India,' etc., etc. The contributions of Chinese missionaries to an accurate knowledge of the literature of China are also well known, such as Dr. Legge's many volumes of the Chinese classics, and the learned works of Drs. Chalmers, Edkins, Milne, and Morrison, and others.

Both philology and literature and folk-lore would be in a bad way were we dependent upon colonists and traders for our knowledge of such subjects; and had not Christian missionaries in all parts of the world, in addition to their chief work of making known the gospel, been determined to study accurately for themselves the languages and ideas of the peoples among whom they live. I therefore have no hesitation in again affirming that missionaries, notwithstanding the disparaging remarks often made about them by those who know least about what they do, have done, and are doing, valuable service to philological and anthropological science.

JAMEs Sibree, Missionary of the L.M.S.

L.M.S. College, Antananarivo, Madagascar, September 29, 1906.

\section{The Phœnician Periplus of Africa.}

I am sorry that my remarks on this subject had to be compressed into so small a space as to lay me open to the criticism pronounced by Mr. Heawood on my letter. To him I would reply-briefly again-as follows. I am not the first to observe that the Phœnician legend, with its impossible harvest-story, would have found little, if any, support in modern times but for the supposition that the alleged report 